Plant Tissue Cult. \& Biotech. 27(1): 85-88, 2017 (June)

\title{
In vitro Shoot Proliferation through Cotyledonary Node and Shoot Tip Explants of Ficus religiosa L.
}

\section{Mohsen Hesami ${ }^{1 *}$, Mohammad Hosein Daneshvar ${ }^{1}$ and Amin Lotfi $^{2}$}

Department of Horticulture Science, University of Tehran, Karaj, 14176-14418, Iran

Key words: Ficus religiosa, Regeneration, Shoot proliferation

Efficient plant regeneration was achieved from cotyledonary node and shoot tip explants of Ficus religiosa. Maximum shoot multiplication was obtained on MS medium supplemented with $1.0 \mathrm{mg} / 1 \mathrm{TDZ}$ in combination with $0.1 \mathrm{mg} / \mathrm{l} \mathrm{IBA}$. Rooting of the shoots was obtained on MS supplemented with $2.0 \mathrm{mg} / \mathrm{l}$ IBA. Regenerated plantlets were acclimated and successfully transplanted to soil. This protocol can be used as a basic tool for commercial propagation of Ficus religiosa.

Ficus religiosa L. (Moraceae) is a deciduous tree native of the sub-Himalayan tract, Bengal and central India. It is widely cultivated in various areas of the world (Hassan et al. 2009). Different parts of this plant have been used traditionally for the treatment of different diseases such as anti-diabetic, antibacterial, anticonvulsive and antinephropathic (Siwach and Gill 2013). Conventionally the plant is propagated through seeds and stem cutting, however these methods are not efficient under varied climatic conditions.

In vitro shoot regeneration has already been reported for F. religiosa (Jaiswal and Narayan 1985, Deshpande et al. 1998, Hassan et al. 2009, Siwach and Gill 2011, 2013). No report has been found in the literature on plant regeneration from immature-explants of F. religiosa. Therefore, the present work was aimed at studying the in vitro regeneration potential of $F$. religiosa from cotyledonary node and shoot tip explants in MS supplemented with different plant growth regulators.

The seeds of $F$. religiosa were collected from 45 - 50 years old F. religiosa mother plants in a field grown at campus of Ramin Agriculture and Natural Resources University, Ahwaz, Iran. The seeds were washed under running water

*Author for correspondence: <mohsenhessami33@ut.ac.ir>. ${ }^{1}$ Department of Horticulture science, Ramin University of Agriculture and Natural Resources, Khuzestan, 63417-73637, Iran. ${ }^{2}$ Department of Agronomy and Plant Breeding, Ramin University of Agriculture and Natural Resources, Khuzestan, 63417-73637, Iran. 
for $30 \mathrm{~min}$. The seeds were surface sterilized with $70 \%$ aqueous ethanol for $10 \mathrm{sec}$ and dipped into $5 \mathrm{~min}$ in $10 \%(\mathrm{v} / \mathrm{v}) \mathrm{NaOCl}$ solution, and then washed with 3 times in sterilized distilled water. The sterilized seeds were inoculated on onetenth strength MS for germination.

Table 1. Effect of TDZ, BAP, Kn and IBA in MS on morphogenic response of $F$. religiosa from shoot tip and cotyledonary node explants.

\begin{tabular}{cccccc}
\hline \multicolumn{2}{c}{ PGR $(\mathrm{mg} / \mathrm{l})$} & \multicolumn{2}{c}{ Cotyledonary node } & \multicolumn{2}{c}{ Shoot tip } \\
\hline Cytokinin & IBA & $\begin{array}{c}\text { \% of explants } \\
\text { forming shoots }\end{array}$ & $\begin{array}{c}\text { Shoot } \\
\text { number }\end{array}$ & $\begin{array}{c}\text { \% of explants } \\
\text { forming shoots }\end{array}$ & $\begin{array}{c}\text { Shoot } \\
\text { number }\end{array}$ \\
\hline $\begin{array}{c}\text { Control } \\
\text { TDZ }\end{array}$ & $0.0 \mathrm{e}$ & $0.0 \mathrm{~g}$ & $0.0 \mathrm{e}$ & $0.0 \mathrm{~g}$ \\
0.5 & 0.05 & $76.66 \mathrm{a}$ & $10.26 \mathrm{~b}$ & $73.33 \mathrm{a}$ & $9.16 \mathrm{~b}$ \\
1.0 & 0.1 & $80.0 \mathrm{a}$ & $11.53 \mathrm{a}$ & $76.66 \mathrm{a}$ & $10.03 \mathrm{a}$ \\
BAP & & & & & \\
1.0 & 0.1 & $53.33 \mathrm{c}$ & $9.26 \mathrm{~d}$ & $43.33 \mathrm{bc}$ & $7.13 \mathrm{~d}$ \\
1.5 & 0.15 & $66.66 \mathrm{~b}$ & $9.43 \mathrm{c}$ & $46.66 \mathrm{~b}$ & $9.03 \mathrm{c}$ \\
Kn & & & & $33.33 \mathrm{~d}$ & $2.13 \mathrm{f}$ \\
1.0 & 0.1 & $26.66 \mathrm{~d}$ & $3.13 \mathrm{f}$ & $35.66 \mathrm{~cd}$ & $2.53 \mathrm{e}$ \\
2.0 & 0.2 & $50.00 \mathrm{c}$ & $4.06 \mathrm{e}$ & & \\
\hline
\end{tabular}

Means followed by the same letter within columns are not significantly different $(p=0.05)$ using DMRT.

Cotyledonary node and shoot tip $(0.5-1.0 \mathrm{~cm})$ were excised from 20-day-old seedlings (Fig. 1a) and were placed on MS supplemented with BA (1.0, $1.5 \mathrm{mg} / \mathrm{l})$, $\mathrm{Kn}(1.0,2.0 \mathrm{mg} / \mathrm{l})$ or TDZ $(0.5,1.5 \mathrm{mg} / \mathrm{l})$ in combination with IBA, in the presence of light. The ratio of cytokinin to auxin in the media was $10: 1$. The $\mathrm{pH}$ of all the media was adjusted to 5.8 and solidified with $0.7 \%$ agar before autoclaving and sterilization was done at $121.5^{\circ} \mathrm{C}$ with 15 psi for $20 \mathrm{~min}$. All the cultures were incubated at $25 \pm 2^{\circ} \mathrm{C}$. The cultures were subcultured on the same fresh medium after three weeks. The data for per cent response and shoot number were recorded after eight weeks.

The elongated in vitro shoots $(2-3 \mathrm{~cm})$ were transferred to induce roots in basal MS and fortified individually with different concentrations of IBA or NAA. The per cent response and root number were recorded after four weeks.

All the experiments were repeated thrice with ten replicates. The data were analyzed using ANOVA and mean separation were carried out using DMRT at $p=0.05 \%$ level of significance. 

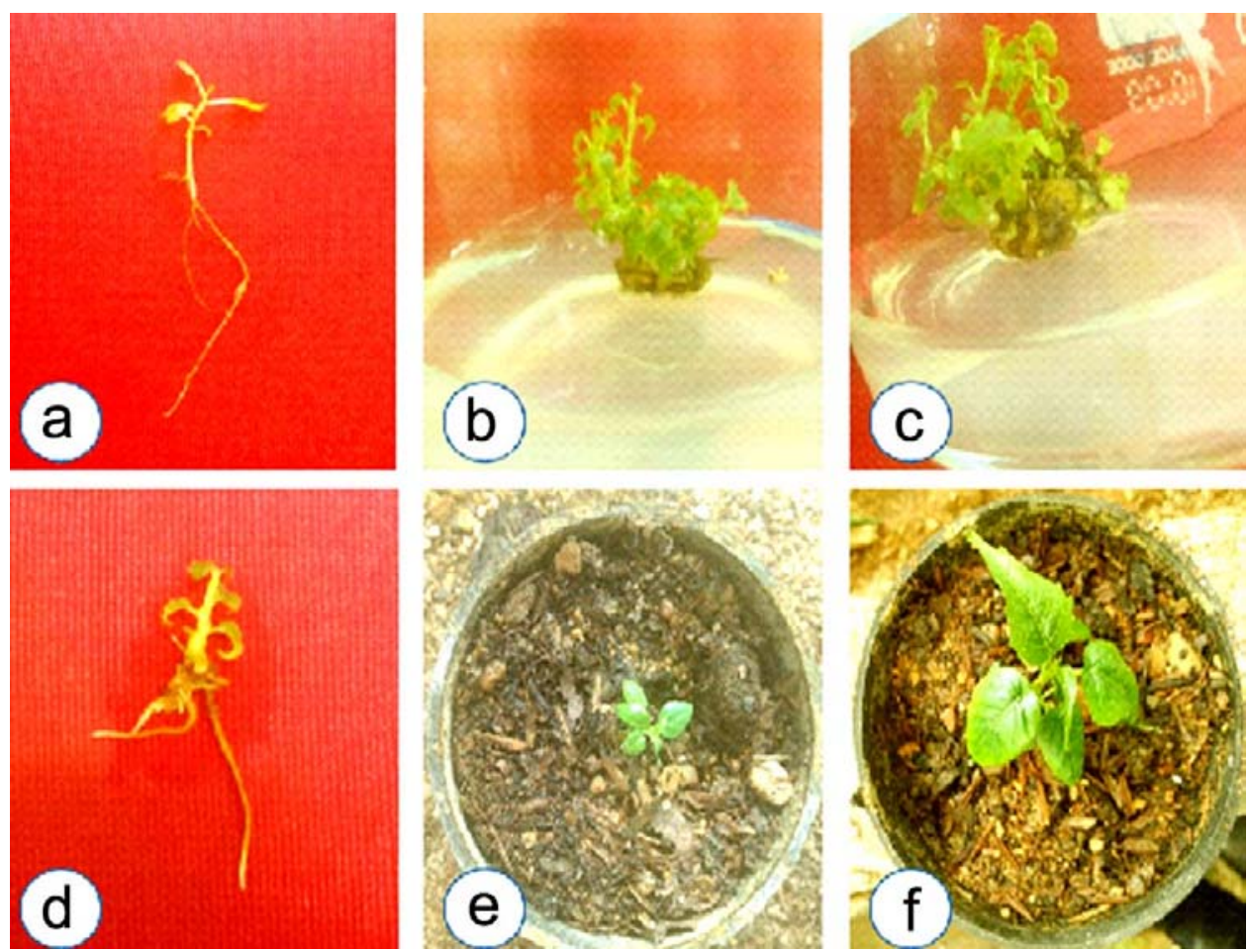

Fig. 1. Shoot proliferation of Ficus religiosa from cotyledonary node and shoot tip explants. a. Seedling from in vitro seed germination, b. shoot multiplication after eight weeks of culture from cotyledonary node and c. shoot tip, d. rooting of in vitro regenerated shoots in four weeks, e. acclimatized regenerated plants after one month and (f) eight weeks.

The explants (Cotyledonary node and shoot tip) were inoculated on MS supplemented with TDZ $(1.5 \mathrm{mg} / \mathrm{l})+$ IBA $(0.1 \mathrm{mg} / \mathrm{l})$ produced large number micro-shoots cotyledonary node $(80 \%)$ and shoot tip $(76.66 \%)$ explants (Table 1 , Fig. 1b,c). Trivedi and Joshi (2014) reported that MS fortified with TDZ was suitable for shoot regeneration of cotyledonary node of Stereospermum suaveolens.

The best root induction was found on $2.0 \mathrm{mg} / \mathrm{l}$ IBA (Table 2 and Fig. 1d). Hassan et al. (2009) reported similar results in Ficus religiosa.

Plantlets with well-developed roots were removed from culture, washed thoroughly with sterile water and transferred to potting mixture comprising autoclaved perlite and vermiculite mixture $(1: 1)$. The plantlets were covered with transparent plastic to maintain the high humidity and were watered once a day and kept in culture room. The plastic sheets were removed periodically. After 30 days, the plantlets were shifted to the soil. About 85 per cent of the transplanted plants of Ficus religiosa survived (Fig. 1e,f). Similar results were reported by Siwach and Gill (2011) in Ficus religiosa. 
Table 2. Effect IBA and NAA on root induction in regenerated shoots of F. religiosa on MS.

\begin{tabular}{ccc}
\hline Auxins $(\mathrm{mg} / \mathrm{l})$ & \% of shoots producing roots & No. of roots/shoot \\
\hline Control & $0.0 \mathrm{f}$ & $0.0 \mathrm{~g}$ \\
IBA & & \\
1.0 & $53.33 \mathrm{c}$ & $3.56 \mathrm{c}$ \\
1.5 & $70.0 \mathrm{~b}$ & $3.70 \mathrm{~b}$ \\
2.0 & $8.33 \mathrm{a}$ & $4.03 \mathrm{a}$ \\
NAA & & \\
0.5 & $26.66 \mathrm{e}$ & $2.43 \mathrm{f}$ \\
1.0 & $36.66 \mathrm{~d}$ & $2.63 \mathrm{e}$ \\
1.5 & $43.33 \mathrm{~d}$ & $2.76 \mathrm{~d}$ \\
\hline
\end{tabular}

Means followed by the same letter within columns are not significantly different $(p=0.05)$ using DMRT.

The present study showed a well-documented and useful protocol of Ficus religiosa with much higher rate of proliferation. This protocol seems to have enough potentiality for micropropagation.

\section{References}

Deshpande SR, Josekutty PC and Prathapasenam G (1998) Plant regeneration from axillary buds of a mature tree of Ficus religiosa. Plant Cell Rep. 17(6-7): 571-573.

Hassan AKMS, Afroz F, Jahan MAA and Khatun R (2009) In vitro regeneration through apical and axillary shoot proliferation of Ficus religiosa - A multipurpose woody medicinal plant. Plant Tissue Cult. Biotechnol. 19(1): 71-78.

Jaiswal VS and Narayan P (1985) Regeneration of plantlets from the callus of stem segments of adult plants of Ficus religiosa. Plant Cell Rep. 4: 256-258.

Salmi MS and Hesami M (2016) Time of collection, cutting ages, auxin types and concentrations influence rooting Ficus religiosa stem cuttings. J. Appl. Environ. Biol. Sci. 6(1): 124-132.

Siwach P and Gill AR (2011) Enhanced shoot multiplication in Ficus religiosa in the presence of adenine sulphate, glutamine and phloroglucinol. Physiol Mol Biol Plants. 17(3): 271-280.

Siwach P and Gill AR (2013) Micropropagation of Ficus religiosa via leaf explants and comparative evaluation of acetylcholinesterase inhibitory activity in the micropropagated and conventionally grown plants. 3 Biotech. DOI 10.1007/s13205013-0175-8.

Trivedi DR and Joshi AG (2014) In vitro shoot regeneration of Stereospermum suaveolens using cotyledonary node and nodal explants. Plant Tissue Cult. \& Biotechnol. 24(2): 235-246. 